\title{
PENGARUH KUALITAS PELAYANAN PUBLIK TERHADAP KEPUASAN MASYARAKAT DI KANTOR KECAMATAN JAYANTI
}

\author{
Mila Alfionita ${ }^{1}$, Iba Gunawan ${ }^{2}$ \\ Universitas Banten Jaya \\ Serang, Indonesia \\ milaalfionita@unbaja.ac.id ${ }^{1}$, ibagunawan@unbaja.ac.id ${ }^{2}$
}

\begin{abstract}
This study aims to determine the effect of service quality on community satisfaction in the Jayanti District office. Samples taken by researchers are 100 respondents from a total population of 60,091 inhabitants. For data collection in this study using a questionnaire.The analysis technique used to see the effect of service quality on community satisfaction in the Jayanti District office is a quantitative method that uses SPSS calculations.The results showed that there was a close relationship between service quality and community satisfaction as seen from the results of the coefficient obtained at $72.7 \%$. Partially shows that the significant value for the effect of service quality on community satisfaction is $0.042<0.05$ and tcount $2.648>t$ table 1.665, so Ho is rejected and Ha is accepted. This means that there is an influence between service quality and community satisfaction.
\end{abstract}

Keywords : quality service, community satisfaction

\section{A. PENDAHULUAN}

Pelayanan publik pada sektor pemerintahan merupakan wujud dari fungsi aparatur Negara dalam bentuk pengabdian kepada masyarakat serta pengabdian terhadap Negara. Pelayanan merupakan salah satu faktor penting dalam suatu pemerintahan yang dapat menentukan kualitas jasa. Suatu kualitas sangat besar pengaruhnya terhadap kepuasan masyarakat.

Salah satu tugas penting yang tidak dapat diabaikan pemerintah pusat maupun daerah adalah pelayanan publik (public service), karena jika pelayanan kepada publik terjadi stagnasi, maka dapat dipastikan akan berdampak pada hampir semua sektor sperti terjadinya kemacetan atau kekacauan. Oleh karena itu pada pengelolaan sektor pemerintah, perencanaan yang baik perlu dilakukan dan bahkan perlu diformulasikan sebuah standar pelayanan pemerintah pada masyarakat sesuai dengan kewenangan yang diberikan baik oleh pemerintah pusat mapupun pada pemerintah daerah. Pelayanan publik pada konteks negara modern, merupakan tuntutan yang semakin penting pada sebuah lembaga dan atau sebuah profesi. Hal ini sudah tidak lagi menjadi sebuah aktivitas sambilan, tanpa payung hukum, gaji dan jaminan sosial yang memadai, seperti yang terjadi di Indonesia saat ini. 
Pola pikir aparatur pemerintah/pemberi layanan cenderung menganggap bahwa sebaik apapun dalam memberikan pelayanan kepada masyarakat, tidak akan merubah gaji dan pendapatannya. Mereka melayani karena adanya tanggung jawab tugas, dan fungsi pemerintahan. Kenyataan ini memperlihatkan bahwa kinerja aparatur pemerintahan masih belum menunjukkan kualitas pelayanan publik yang diharapkan. Peraturan yang ada seringkali tidak mudah dipahami oleh warga pengguna layanan yang sebagian besar berpendidikan rendah, sehingga banyak terjadi mis-komunikasi antara yang melayani dengan yang dilayani.

Kondisi pelayanan seperti ini merupakan konsekuensi kurang efektifnya sosialisasi kebijakan pelayanan kepada warga, disamping itu warga/masyarakat memang tidak dilibatkan dan tidak diajak bicara tentang masalah pelayanan, perumusan tentang kebijakan pelayanan seperti penetapan biaya, SOP, time frame pelayanan dan sebagainya, hanya dilakukan sepihak oleh pemerintah. Artinya bahwa masyarakat pada umumnya hanya ditempatkan sebagai obyek pelayanan yang hanya mendapatkan diperlakuan sesuai standar aparatur pemerintah itu sendiri. Dengan demikian tidak heran jika sering mendengarkan tuntutan perubahan dari masyarakat yang ditujukan kepada aparatur pemerintah, terkait pelayanan publik yang diberikan kepada masyarakat. Rendahnya mutu pelayanan pemerintah kepada publik akan memberikan performa buruk bagi pemerintah ditengah masyarakat secara umum. Bagi masyarakat yang pernah bersentuhan dengan proses birokrasi dipemerintahan selalu mengeluh dan kecewa terhadap aparat pemerintah yang memberikan pelayanan.

Pelayanan merupakan tugas utama bagi aparatur negara sebagai abdi negara dan abdi masyarakat. Tugas ini secara jelas telah digariskan dalam pembukaan UndangUndang Dasar 1945 alinea ke-empat, yang meliputi empat aspek pelayanan pokok aparatur terhadap masyarakat yang berbunyi: Melindungi segenap bangsa dan seluruh tumpah darah Indonesia memajukan kesejahteraan umum dan mencerdaskan kehidupan bangsa.

Lembaga atau organisasi pemerintah semakin dituntut untuk menciptakan kualitas pelayanan yang dapat mendorong dan meningkatkan kegiatan ekonomi masyarakat. Oleh sebab itu, pelayanan (service) seorang aparatur pemerintah harus lebih cermat dan proaktif dalam menghadapi paradigma baru secara global sehingga pelayanannya mampu memenuhi keinginan serta kebutuhan masyarakat luas yang dinamis. 
Banyak hal yang menyebabkan belum optimalnya penyelenggaraan pelayanan publik, salah satunya adalah kualitas pelayanan yang diberikan aparatur pada instansi pemerintahan kepada masyarakat belum memenuhi persayaratan dimensi kualitas pelayanan yang baik seperti bukti fisik (tangible), empati (emphaty), daya tanggap (responsiveness), keandalan (reliability), jaminan (assurance).

Pelayanan publik menarik untuk dicermati karena kegiatannya dilakukan dalam rangka pemenuhan kebutuhan dasar warga Negara atas suatu barang atau jasa serta pelayanan administrasi yang terkait dengan kegiatan publik pula. Orientasi sebuah kegiatan publik adalah barangbarang publik dan pelayanan publik dimana didalam dinamika kehidupan masyarakat modern bahwa yang berperan sebagai konsumen adalah mereka yang akan selalu berhubungan atau terkait dengan kegiatankegiatan pelayanan publik. Selain itu perlu diketahui bersama bahwa sumber dana kegiatan pelayanan publik yang diselenggarakan pemerintah adalah berasal dari masyarakat melalui pajak sehingga wajar apabila masyarakat mengharapkan adanya pelayanan yang maksimal, baik serta berkualitas.

Pemerintah kecamatan sebagai salah satu unsur pemerintahan tidak luput dengan konsep dasar pelayanan yang harus dilakukan dengan cepat, karena kebutuhan masyarakat yang semakin banyak, mengharuskan pegawai kecamatan yang ada di wilayah untuk selalu meningkatkan kemampuan, pengetahuan dan keterampilan agar dapat melayani masyarakat dengan baik.

Untuk menjamin kualitas pelayanan yang baik serta terukur kepada masyarakat oleh aparatur pemerintah, maka Pemerintah mengeluarkan peraturan yang tertuang dalam sebuah Keputusan Menteri Pendayagunaan Aparatur Negara Nomor: 63/KEP/M.PAN/7/2003 tentang Pedoman Umum Penyelenggaraan Pelayanan Publik. Namun demikian langkah kebijakan yang telah diambil pemerintah ini tidak akan bisa dicapai secara maksimal apabila aparatur pemerintah tidak bekerja secara optimal. Oleh karena itu, kebijakan yang dikeluarkan oleh Menteri Pendayagunaan Aparatur Negara dalam upaya meningkatkan kualitas pelayanan harus diimbangi dengan upaya optimalisasi kinerja aparatur pemerintah dan melakukannya secara konsisten dengan memperhatikan segala kebutuhan dan harapan masyarakat.

Upaya optimalisasi kinerja aparatur pemerintah sebenarnya sudah dilakukan oleh pemerintah melalui perubahan Undang-Undang Nomor 18 Tahun 1974 menjadi Undang-Undang Nomor 43 Tahun 1999 tentang Pokok-Pokok Kepegawaian. 
Di sisi lain untuk meningkatkan kinerja aparatur pemerintah, pemerintah juga mengeluarkan kebijakan lain berupa Peraturan Pemerintah Nomor 101 Tahun 2000 tentang Diklat Jabatan PNS dan terakhir mengenai Surat Keputusan Menteri Pendayagunaan Aparatur Negara Nomor KEP/26/M.PAN/2/2004 tentang Petunjuk Teknis Transparansi dan Akuntabilitas dalam Penyelenggaraan Pelayanan Publik. Alasan umum dari kebijakan yang diambil pemerintah ini adalah karena pemerintah sedang berupaya untuk semaksimal mungkin mempercepat mewujudkan pelayanan kepada publik yang baik dan berkualitas.

Pelayanan publik (Public Service) berpedoman pada prinsip profesionalisme serta etika pubilk diantaranya acountability, effectivenness, efficiency, integrity, neutrality, dan fairness untuk semua yang menerima pelayanan. Memberikan pelayanan yang baik dan berkualitas merupakan tugas utama bagi seluruh aparatur Negara sebagai abdi Negara dan abdi masyarakat. Pelayanan publik adalah salah satu tugas terpenting babi pemerintah daerah yang tidak dapat diabaikan begitu saja, sebab jika saja pelayanan mengalami stagnasi maka hampir dipastikan berdampak kepada semua sektor terkait. Oleh sebab itu perlu dilakukan perencanaan yang baik dan bahkan diformulasikan suatu standar pelayanan pada masyarakat sesuai dengan kewenangan yang diberikan oleh pemerintah baik pusat maupun daerah.

Sebagai konsekuensi dari pelaksanaan otonomi daerah terlebih setelah ditetapkannya Undang-undang nomor 32 Tahun 2004 tentang pemerintahan daerah, di mana pemerintahan daerah diberi kewenangan yang demikian luas oleh pemerintah pusat untuk mengatur rumah tangga daerahnya sendiri, termasuk didalamnya adalah pemberian pelayanan kepada masyarakat di daerahnya. Dari berbagai isu yang timbul dikalangan masyarakat pengguna layanan pemerintah, masih muncul penilaian bahwa hak pelayanan yang dirasakan oleh masyarakat masih terasa belum sesuai atau memenuhi harapan masyarakat, baik dari kalangan masyarakat secara umum maupun dari kalangan pemerintahnya sendiri.

Pelayanan Publik dapat dimaknai sebagai pemberian jasa layanan (melayani) berbagai keperluan orang atau pengguna jasa layanan (masyarakat) yang mepunyai kepentingan pada organisasi tersebut sesuai dengan peraturan pokok serta tata cara yang telah ditentukan. Kewajiban yang melekat pada pemerintah daerah sebagai penyelenggara utama pelayanan publik adalah untuk melayani secara lebih baik kebutuhan publik sesuai dengan prinsipprinsip tata kelola pemerintahan yang baik 
(good governance) serta demokratis.

Memberikan pelayanan kepada publik yang dilakukan oleh penyelenggara pelayanan publik (pemerintah daerah) merupakan kegiatan yang harus dilakukan secara terusmenerus dan berkesinambungan seiring dengan harapan masyarakat yang senantiasa menuntut dilakukannya peningkatan kualitas pelayanan publik.

Profesionalisme pemerintah saat ini sedang mengalami kemuduruan. Banyak para pejabat politik serta pemerintah yang duduk didalam birokrasi, belum mendukung sepenuhnya atau dapat dipercaya dalam menyelenggarakan pemerintahan yang bersih dan berwibawa sehingga terselenggaranya pemerintahan yang menyelenggarakan prinsip good governance. Dipahami atau tidak pejabat pemerintah mempunyai peran penting dalam memulihkan kepercayaan masyarakat kepada pemerintahan dengan langkah menciptakan lingkungan kerja sehingga sesuai dengan standar profesionalisme. Untuk itu bidang pelayanan publik masih perlu mendapat perhatian dan pembenahan secara sungguhsunguh dan menyeluruh dalam berbagai sektor yang menjadi pendukung terselenggaranya pelayanan publik yang efektif sehingga dapat menjawab tantangan yang ada berupa pelayanan yang profesional dalam rangka memenuhi tuntutan masyarakat pengguna.

Pada kondisi yang demikian, tentu sudah menjadi tugas pemerintah dalam hal mewujudkan pelayanan secara profesional yang dibutuhkan oleh masyarakat luas. Pelayanan publik yang baik menjadi isu kebijakan yang strategis karena pelayanan publik sangat berimplikasi luas khususnya dalam memperbaiki kepercayaan kepada pemerintah. Suatu fenomena yang sekaligus menjadi masalah utama yaitu belum optimalnya kinerja aparatur pemda dalam menjalankan tugas dan fungsinya, yang ditunjukkan masih banyaknya keluhankeluhan yang disampaikan masyarakat atas pelayanan yang diberikan pemda selama ini. Oleh karena itu perbaikan pelayanan publik mutlak diperlukan agar kesan buruk masyarakat kepada pemerintah dapat diperbaiki, karena dengan perbaikan kualitas pelayanan publik dapat mempengaruhi kepuasan masyarakat sehingga kepercayaan masyarakat terhadap pemerintah dapat dibangun kembali.

Dapat disimpulkan bahwa kantor kecamatan harus selalu meningkatkan kualitas pelayanan agar tercipta kepuasan yang dapat dirasakan oleh masyarakat sekitar. Masyarakat merasa puas jika kinerja yang dirasakan sesuai ekspektasinya, sebaliknya masyarakat akan 
merasa kecewa jika kinerja yang dirasakan dibawah ekspektasinya.

Berdasarkan latar belakang yang dijelaskan, penulis tertarik untuk mengkaji lebih dalam tentang "Pengaruh Kualitas Pelayanan Publik Terhadap Kepuasan Masyarakat di Kantor Kecamatan Jayanti”.

\section{Kerangka Pemikiran}

Untuk mengukur tingkat kepuasan masyarakat, belum ada standar pedoman yang pasti, hal ini dikarenakan kepuasan itu bersifat relatif terlebih harapan dan interprestasi pelanggan berbeda-beda pula. Akan tetapi secara empirik kepuasan pelanggan dapat dipahami dengan meneliti 5 (lima) dimensi kualitas pelayanan yaitu: Reliability (kehandalan), assurance (jaminan), responsive (daya tanggap), tangible (bukti fisik), dan emphaty (empati).

Ketidakpuasan akan timbul jika harapan dan keinganan konsumen tidak sesuai dengan kualitifikasi pelayanan yang diterimanya. Secara sistematik, kerangka berpikir dalam penelitian ini dapat digambarkan sebagai berikut:

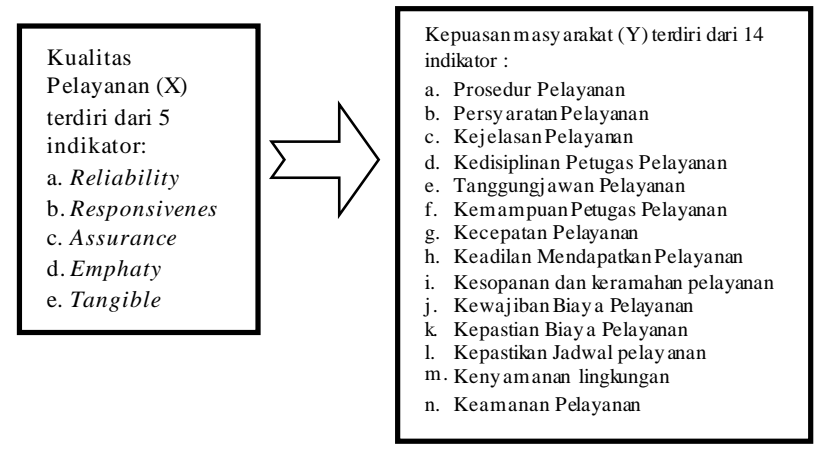

\section{Gambar 1. Kerangka Pemikiran}

\section{Hipotesis}

Berdasarkan masalah pada pokok penelitian dan tujuan yang ingin dicapai, maka sebagai hipotesis pada penelitian ini adalah :

Ho : Tidak ada pengaruh yang signifikan dari variabel independen yaitu Kualitas Pelayanan (X) terhadap variabel dependen yaitu Kepuasan Masyarakat (Y).

Ha : Terdapat pengaruh yang signifikan dari variabel independen yaitu Kualitas Pelayanan (X) terhadap variabel dependen yaitu Kepuasan Mayarakat (Y).

\section{B. METODE PENELITIAN}

Penelitian ini dilakukan di Kantor Kecamatan Jayanti, Kabupaten Tangerang. Alasan pemilihan Kecamatan Jayanti sebagai tempat penelitan merupakan Kecamatan dengan jumlah desa terbesar di Kabupaten Tangerang, kegiatan penelitian ini dilakukan pada Februari 2019 sampai dengan selesai.

Didalam penelitian ini yang menjadi subjek penelitian yaitu Masyarakat Jayanti. Pengumpulan data dalam penelitian ini menggunakan angket kuesioner. Dimana angket kuesioner tersebut berisi petunjuk pengisian angket kuesioner, identitas responden yang terdiri dari nama, umur, jenis kelamin, keterangan tentang 
pemberian skor dari setiap pertanyaan, dan yang terakhir terdapat beberapa pertanyaan yang diajukan kepada responden.

Karena banyaknya responden dalam penelitian ini, maka angket yang digunakan adalah angket tertutup, dimana responden hanya memilih jawaban yang telah disediakan.

1. Instrumen Kualitas Pelayanan Publik

Instrumen kualitas pelayanan disusun berdasarkan indikator kualitas pelayanan publik. Instrumen kualitas pelayanan dijabarkan menjadi 20 butir pernyataan. Kisi-kisi instrumen pada variabel kualitas pelayanan publik dapat dilihat pada tabel sebagai berikut:

Tabel 1. Instrumen

Kualitas Pelayanan Publik

\begin{tabular}{|c|c|c|c|}
\hline No. & Indikator & No. Butir & Jumlah \\
\hline 1. & $\begin{array}{l}\text { Realibility } \\
\text { (Kehandalan) }\end{array}$ & $1,2,3,4$ & 4 \\
\hline 2. & $\begin{array}{l}\text { Responsivenes } \\
\text { (Ketanggapan) }\end{array}$ & $1,2,3,4$ & 4 \\
\hline 3. & Assurance (Jaminan) & $1,2,3,4$ & 4 \\
\hline 4. & Emphaty (Empati) & $1,2,3,4$ & 4 \\
\hline \multirow[t]{2}{*}{5.} & $\begin{array}{l}\text { Tangible (Hal-hal } \\
\text { yang terlihat) }\end{array}$ & $1,2,3,4$ & 4 \\
\hline & Jumlah & & 20 \\
\hline
\end{tabular}

2. Instrumen Kepuasan Pelanggan

Instrumen kepuasan masyarakat disusun berdasarkan indicator kepuasan masyarakat. Instrumen kepuasan masyarakat dijabarkan menjadi 14 butir pernyataan. Kisi-kisi instrumen pada variabel kepuasan masyarakat dapat dilihat pada tabel sebagai berikut:

Tabel 2. Instrumen Kepuasan Masyarakat

\begin{tabular}{|c|c|c|c|}
\hline No. & Indikator & No. Butir & Jumlah \\
\hline 1 & ProsedurPelayanana & 1,2 & 2 \\
\hline 2 & Persyaratan Pelayanan & 3,4 & 2 \\
\hline 3 & Kejelasan Pelayanan & 5 & 1 \\
\hline 4 & $\begin{array}{l}\text { Kedisiplinan } \\
\text { Petugas }\end{array}$ & 6 & 1 \\
\hline 5 & $\begin{array}{l}\text { Tanggung Jawab } \\
\text { Pelayanan }\end{array}$ & 7 & 1 \\
\hline 6 & $\begin{array}{l}\text { Kemampuan } \\
\text { Petugas }\end{array}$ & 8 & 1 \\
\hline 7 & Kecepatan Pelayanan & 9 & 1 \\
\hline 8 & $\begin{array}{l}\text { Keadilan Mend apatkan } \\
\text { Pelayanan }\end{array}$ & 10,11 & 2 \\
\hline 9 & $\begin{array}{l}\text { Kesopanan dan } \\
\text { Keramahan }\end{array}$ & 12 & 1 \\
\hline 10 & $\begin{array}{l}\text { Kewajiban Biaya } \\
\text { Pelayanan }\end{array}$ & 13 & 1 \\
\hline 11 & $\begin{array}{l}\text { Kepastian Biaya } \\
\text { Pelayanan }\end{array}$ & 14,15 & 2 \\
\hline 12 & $\begin{array}{l}\text { Kepastian Jadwal } \\
\text { Pelayanan }\end{array}$ & 16 & 1 \\
\hline 13 & $\begin{array}{l}\text { Kenyamanan } \\
\text { Lingkungan }\end{array}$ & 17,18 & 2 \\
\hline \multirow[t]{2}{*}{14} & Keamanan Pelayanan & 19,20 & 2 \\
\hline & Jumlah & & 20 \\
\hline
\end{tabular}

3. Teknik Analisis Data

Pada tahap proses analisis data penelitian, teknik yang digunakan pada penelitian ini adalah teknik analisis kuantitatif. Analisis kuatitatif merupakan analisis data berdasarkan perhitungan statistik untuk menjawab permasalahan yang ada. Untuk penganalisa pengaruh antara variabel-variabel yang ada tersebut menggunakan (1) Uji Normalitas; (2) Uji 
Multikolieniearitas dan (3) Uji Regresi

Linier Berganda.

Dalam pengujian hipotesis, uji statistik yang digunakan dilakukan melalui 3 (tiga) metode pendekatan yaitu (1) Uji Parsial (T-test); (2) Koefisien determinasi (acdjust $\mathrm{R}^{2}$ ) dan (3) Uji Simultan (F-test).

\section{HASIL PENELITIAN DAN PEMBAHASAN}

Kecamatan Jayanti berada di wilayah Kabupaten Tangerang Provinsi Banten dan terdiri dari 8 (delapan) desa.

Secara administratif, Kecamatan Jayanti, memiliki luas $23.89 \mathrm{KM}^{2}$ atau sekitar 2,5\% dari luas wilayah Kabupaten Tangerang. Topografi wilayah Kecamatan Jayanti relatif datar dengan ketinggian antara 0-20 mdpl. Ketinggian 0-20 mdpl berada di Desa Pasirgintung, Pangkat, Cikande, Sumurbandung dan Desa Dangdeur, dengan luas keseluruhannya 18,89 $\mathrm{KM}^{2}$ atau sekitar $79,07 \%$ dari luas wilayah Kecamatan Jayanti. Untuk ketinggian 20-40 mdpl berada di Desa Pabuaran, Jayanti dan Desa Pasirmuncang dengan luas keseluruhan 5,00 $\mathrm{KM}^{2}$ atau sekitar 20,92\% dari luas wilayah.

Jumlah penduduk Kecamatan Jayanti sebanyak 60.091 jiwa yang terdiri dari Laki-laki sebanyak 30.736 jiwa dan Perempuan sebanyak 29.355 jiwa. Jika dibandingkan antara jumlah penduduk dengan luas wilayah, Kecamatan Jayanti, memiliki kepadatan penduduk sekitar $22,606 \mathrm{jiwa} / \mathrm{KM}^{2}$.

\section{Hasil Penelitian}

Uji Validitas

Berdasasrkan hasil uji coba instrumen dengan menggunakan bantuan program SPSS 23 for Windows diperoleh hasil uji validitas instrument penelitian bahwa indikator-indikator dari variabel kualitas pelayanan yang dikembangkan menjadi 20 butir pernyataan dinyatakan 2 butir pernyataan tidak valid yaitu nomor 7 dan 20.

Selanjutnya hasil uji coba instrumen pada variable kepuasan masyarakat diperoleh hasil uji validitas instrument penelitian bahwa indikator-indikator dari variabel kepuasan masyarakat yang dikembangkan menjadi 20 butir pernyataan dinyatakan 3 butir pernyataan tidak valid yaitu nomor 2,3 dan 9 .

Reliabilitas

Berdasarkan hasil uji coba dengan menggunakan komputer program SPSS version 23 diperoleh rangkuman yang dapat dilihat pada tabel dibawah ini: 
Tabel 3. Hasil Uji Reliabilitas

\begin{tabular}{clccc}
\multicolumn{5}{c}{ Variabel $(\mathbf{X})$} \\
\hline No & Variabel & $\begin{array}{c}\boldsymbol{r} \text { Conbrach } \\
\text { alpha }\end{array}$ & Reliabilitas & Ket. \\
\hline 1 & Reliability & .769 & $0,60$. & Reliabel \\
2 & Responsivenes & .616 & $0,60$. & Reliabel \\
3 & Assurance & .752 & $0,60$. & Reliabel \\
4 & Emphaty & .738 & $0,60$. & Reliabel \\
5 & Tangible & .649 & $0,60$. & Reliabel
\end{tabular}

Sumber: Data pimer diolah (2019)

Tabel 4. Hasil Uji Reliabilitas

\begin{tabular}{ccccc}
\multicolumn{4}{c}{ Variabel (Y) } \\
\hline No & Variabel & $\begin{array}{c}\text { r Conbrach } \\
\text { alpha }\end{array}$ & Reliabilitas & Ket. \\
\hline 1 & $\begin{array}{l}\text { Kepuasan } \\
\text { Masyarakat }\end{array}$ & 0,800 & $0,60$. & Reliabel \\
\hline
\end{tabular}

Sumber: Data pimer diolah (2019)

Hasil uji reliabilitas menunjukkan bahwa semua item pernyatan dari beberapa item yang diteliti adalah reliabel karena mempunyai nilai Cronbach Alpha $>0,60$.

Uji Normalitas

Berikut diperoleh hasil analisis data dengan uji normalitas:

\begin{tabular}{|c|c|c|}
\hline & & $\begin{array}{c}\text { Unstandardized } \\
\text { Residual }\end{array}$ \\
\hline $\mathrm{N}$ & & 50 \\
\hline Normal Parameters ${ }^{\mathrm{a}, \mathrm{b}}$ & Mean & .0000000 \\
\hline Most Extreme Differences & $\begin{array}{l}\text { Std. Deviation } \\
\text { Absolute }\end{array}$ & $\begin{array}{r}3.52132883 \\
086\end{array}$ \\
\hline & $\begin{array}{l}\text { Positive } \\
\text { Negative }\end{array}$ & $\begin{array}{r}.056 \\
-.086\end{array}$ \\
\hline Test Statistic & & .086 \\
\hline Asymp. Sig. (2-tailed) & & $.200^{c, d}$ \\
\hline
\end{tabular}

Gambar 2. One Sample KolmogorovSmirnov Test

Berdasarkan hasil uji normalitas diketahui nilai signifikansi $0,200>0,05$ (rtabel) Dengan demikian bahwa uji normalitas variabel Kualitas Pelayanan (X) dan Kepuasan Masyarakat (Y) dinyatakan berdistribusi normal.

Uji Multikolinieritas

Berikut diperoleh hasil analisis data dengan uji Multikolinieritas:

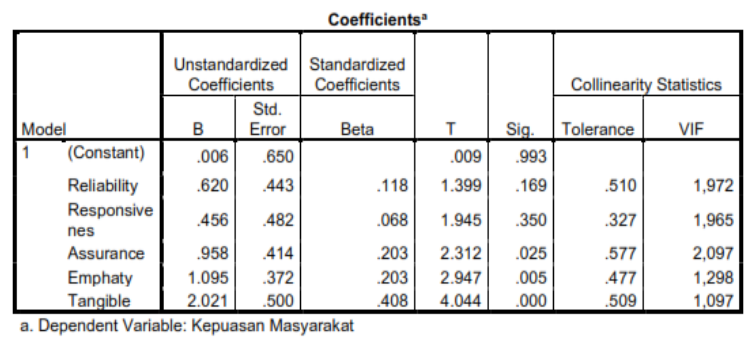

Gambar 3. Uji Multikolinieritas

Berdasarkan tabel Coefficient di atas diperoleh hasil Uji multikolinearitas sebagai berikut:

a. Nilai tolerance Reliability sebesar 0,510 > 0,10 dan nilai VIF sebesar 1,927 < 10,00 maka artinya tidak terjadi multikolinieritas.

b. Nilai tolerance Responsivenes sebesar $0,327>0,10$ dan nilai VIF sebesar $1,965<10,00$ maka artinya tidak terjadi multikolinieritas.

c. Nilai tolerance Assurance sebesar 0,577 $>0,10$ dan nilai VIF sebesar 2,097 < 10,00 maka artinya tidak terjadi multikolinieritas.

d. Nilai tolerance Emphaty sebesar 0,477 > 0,10 dan nilai VIF sebesar 1,298 $<10,00$ maka artinya tidak terjadi multikolinieritas. 
PROGRESS

Jurnal Pendidikan, Akuntansi dan Keuangan

Universitas Banten Jaya
Vol 3 No. 1, Februari 2020

E-ISSN 2622-7037 |P-ISSN 2623-0763 e. Nilai tolerance Tangible sebesar 0,509 >

0,10 dan nilai VIF sebesar 1,097 $<10,00$ maka artinya tidak terjadi multikolinieritas.

Uji Regresi Linier Berganda

\section{Uji $t$}

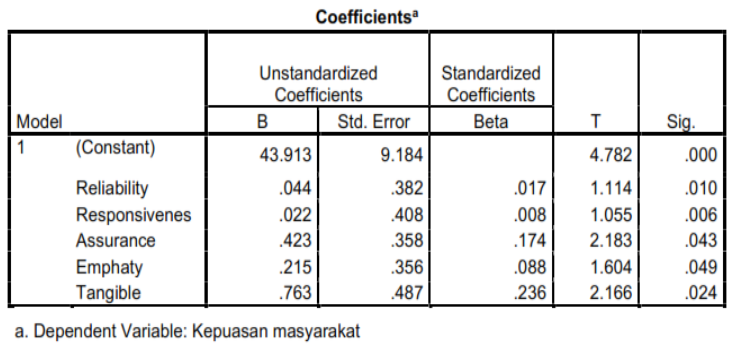

Gambar 4. Uji Multikolinieritas

Berdasarkan hasil Uji $t$ yang telah dilakukan. Diketahui nilai signifikan untuk pengaruh reliability terhadap kepuasan masyarakat adalah sebesar $0,010<0,05$ dari nilai t-hitung 1,114>t-tabel 1,680, sehingga dapat disimpulkan bahwa Ho ditolak dan $\mathrm{Ha}$ diterima, artinya terdapat adanya pengaruh antara indikator reliability terhadap variable kepuasan masyarakat.

Selanjutnya diketahui nilai signifikam untuk pengaruh responsiveness terhadap kepuasan masyarakat adalah sebesar 0,006 $<0,05$ dari nilai t-hitung $1,055>\mathrm{t}$-tabel 1,680, sehingga dapat disimpulkan bahwa Ho ditolak dan Ha diterima, artinya terdapat adanya pengaruh antara indikator responsiveness terhadap variabel kepuasan masyarakat.
Untuk pengaruh assurance terhadap kepuasan masyarakat, diketahui hasil Uji $t$ sebesar $0,043<0,05$ dari nilai t-hitung $2,183>\mathrm{t}$-tabel 1,680, sehingga dapat disimpulkan bahwa Ho ditolak dan $\mathrm{Ha}$ diterima, artinya terdapat adanya pengaruh antara indicator assurance terhadap variabel kepuasan masyarakat.

Kemudian hasil Uji $t$ yang telah dilakukan terkait pengaruh emphaty terhadap kepuasan masyarakat adalah sebesar $0,049<0,05$ dengan nilai t-hitung $1,604>$ t-tabel 1,680, sehingga dapat disimpulkan bahwa Ho ditolak dan $\mathrm{Ha}$ diterima, artinya terdapat adanya pengaruh antara indikator emphaty terhadap variabel kepuasan masyarakat.

Terakhir dari hasil Uji $t$ yang dilakukan, diketahui nilai signifikan untuk pengaruh tangible terhadap kepuasan masyarakat adalah sebesar $0,024<0,05$ dimana nilai t-hitung 2,166 > t-tabel 1,680, sehingga dapat disimpulkan bahwa Ho ditolak dan $\mathrm{Ha}$ diterima, artinya terdapat adanya pengaruh antara indikator tangible terhadap variabel kepuasan masyarakat.

\section{Uji Determinan}

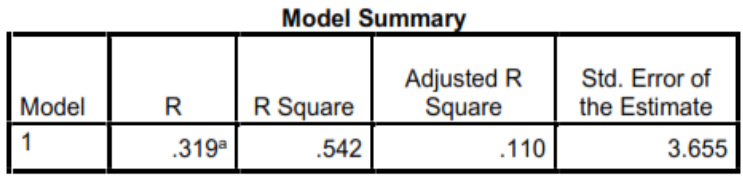

a. Predictors: (Constant), Tangible, Reliability, Emphaty,

Assurance, Responsivenes 
Vol 3 No. 1, Februari 2020

E-ISSN 2622-7037 |P-ISSN 2623-0763
Berdasarkan tabel diatas dapat diketahui nilai $R$ Square sebesar 0,542 atau 54,2\%. Artinya Kualitas Pelayanan mempengaruhi Kepuasan Masyarakat sebesar 54,2\% sedangkan sisanya sebesar $45,8 \%$ dipengaruhi oleh faktor lainnya yang tidak diteliti dalam penelitian ini. Dari hasil perhitungan uji determinasi diatas dapat disimpulkan bahwa pengaruh Kualitas Pelayanan terhadap Kepuasan Masyrakat pada bagian pelayanan publik di Kantor Kecamatan Jayanti pelayanan hanya mempengaruhi sebesar 54,2\%, sedangkan sisanya $45,8 \%$ dipengaruhi oleh faktor lainnya yang tidak diteliti oleh penelitian ini.

\section{Uji Simultan $F$}

\begin{tabular}{|c|c|c|c|c|c|c|}
\hline \multicolumn{7}{|c|}{ ANOVA $^{a}$} \\
\hline & & $\begin{array}{c}\text { Sum of } \\
\text { Squares } \\
\end{array}$ & df & $\begin{array}{c}\text { Mean } \\
\text { Square } \\
\end{array}$ & $\mathrm{F}$ & Sig. \\
\hline \multirow[t]{3}{*}{$\overline{1}$} & Regression & 8.755 & 1 & 8.755 & 2.717 & $.001^{\text {t }}$ \\
\hline & Residual & 315.805 & 98 & 3.223 & & \\
\hline & Total & 324.560 & 99 & & & \\
\hline
\end{tabular}

\section{Gambar 6. Uji Simultan F}

Berdasarkan tabel hasil pengujian Uji Simultan $F$ diatas dapat diketahui $F_{\text {hitung }}$ $2,717>\mathrm{F}_{\text {tabel }} 2,40$ dengan nilai signifikan sebesar $0,001<0,05$. Hasil perhitungan ini menunjukan bahwa semua variabel independen yaitu reliability, responsiveness, assurance, emphaty, dan tangible berpengaruh signifikan secara simultan (bersama-sama) terhadap kepuasan masyarakat. Dengan demikian dapat disimpulkan bahwa hipotesa $\mathrm{Ha}$ diterima dan Ho ditolak.

\section{E. KESIMPULAN DAN SARAN}

\section{Kesimpulan}

Dari hasil pembahasan di atas dapat ditarik kesimpulan sebagai berikut:

1. Penyelenggaran pelayanan oleh pemerintah kepada masyarakat tentu telah memiliki standar pelayanan yang menjadi ukuran yang dibakukan sebagai pedoman dan wajib ditaati dan dilaksanakan oleh penyelenggara pelayanan itu sendiri, selain itu standar pelayanan ini juga menjadi pedoman bagi penerima pelayanan serta sebagai alat kontrol masyarakat dan/atau penerima layanan atas kinerja penyelenggara pelayanan.

2. Secara uji parsial bahwa diketahui nilai signifikan untuk pengaruh reliability terhadap kepuasan masyarakat adalah sebesar $0,010<0,05$ dan nilai t-hitung $1,114>\mathrm{t}$-tabel 1,680, nilai signifikan untuk pengaruh responsiveness terhadap kepuasan masyarakat adalah sebesar $0,006<0,05$ dan nilai t-hitung 1,055 $>$ t-tabel 1,680, nilai signifikan untuk pengaruh assurance terhadap kepuasan masyarakat adalah sebesar 0,043 < 0,05 dan nilai t-hitung $2,183>\mathrm{t}$-tabel 1,680, nilai signifikan untuk pengaruh emphaty terhadap kepuasan masyarakat 
PROGRESS

Jurnal Pendidikan, Akuntansi dan Keuangan

Universitas Banten Jaya
Vol 3 No. 1, Februari 2020 adalah sebesar $0,049<0,05$ dan nilai thitung $1,604>\mathrm{t}$-tabel 1,680 , nilai signifikan untuk pengaruh tangible terhadap kepuasan masyarakat adalah sebesar $0,024<0,05$ dan nilai t-hitung $2,166>$ t-tabel 1,680, sehingga dapat disimpulkan bahwa Ho ditolak dan $\mathrm{Ha}$ diterima, artinya terdapat adanya pengaruh di setiap indikator kualitas pelayanan terhadap variabel kepuasan masyarakat. Dari hasil perhitungan dapat disimpulkan bahwa indikator kualitas pelayanan yang meliputi reliability, responsiveness, assurance, emphaty dan tangible yang paling dominan berpengaruh terhadap kepuasan masyarakat adalah indikator responsiveness (ketanggapan).

Masyarakat akan merasa puas apabila petugas cepat merespon masyarakat yang datang serta mampu mengatasi setiap persoalan masyarakat sesuai dengan kebutuhannya masing-masing.

3. Berdasarkan hasil uji determinan diletahui nilai $\mathrm{R}$ Square sebesar 0,542 atau $54,2 \%$. Artinya kualitas pelayanan mempengaruhi kepuasan masyarakat sebesar $57,2 \%$ sedangkan sisanya sebesar $45,8 \%$ dipengaruhi oleh faktor lainnya yang tidak diteliti dalam penelitian ini.

\section{Saran}

Pada penelitian ini, peneliti memberikan saran yang diharapkan dapat menjadi penambah informasi bagi pihak yang bersangkutan:

1. Kantor Kecamatan Jayanti harus selalu mengevaluasi kinerja seluruh jajaran personilnya untuk perbaikan di segala bidang, yang perlu mendapat perhatian serius adalah ketanggapan aparat kantor Kecamatan Jayanti terhadap kesiapan petugas melayani masyarakat yang datang dan kemauan untuk membantu setiap keluhan masyarakat.

2. Meningkatkan jaminan pelayanan kantor Kecamatan Jayanti dengan jalan selalu dapat menyelesaikan setiap permasalahan yang dilimpahkan masyarakat pada kantor kecamatan Jayanti dan selalu berada di tengahtengah masyarakat sebagai pengayom dan pelindung masyarakat.

3. Diharapkan bagi setiap aparatur pada instansi pemerintahan terus meningkatkan kualitas pelayanan dengan memenuhi setiap persyaratan dimensi kualitas pelayanan yang baik. Agar kedepannya masyarakat selalu merasa puas dengan kualitas pelayanan pada setiap instansi pemerintahan. 


\section{DAFTAR PUSTAKA}

Arikunto, Suharsimi. (2016). Manajemen Penelitian. Jakarta: Rineka Cipta.

Dahmiri \& Suzana, Vera. (2017). Pengaruh Kualitas Pelayanan Terhadap Kepuasan Masyarakat Pada Dinas Kependudukan dan Pencatatan sipil Kabupaten Sarolangun (Studi Pada Mahasiswa Universitas Jmbi). Tersedia: http://repository.unja.ac.id/3353/1/7. 3605-Article Text-7185- 1-1020170420.pdf.

Hardiansyah. (2011). Kualitas Pelayanan Publik. Yogyakarta: GAVA MEDIA.

Muhlisin. (2018). Kepuasan Masyarakat pada Pelayanan dikantor Camat Bayung Lencir Kecamatan Bayung Lencir Kabupaten Banyu Asin. 3(1).59.

Nur Nasution. M. (2004). Manajemen Jasa Terpadu. Bogor: Ghalia Indonesia.

Negara, Indra Jaya. (2017). Pelayanan Publik pada Kecamatan Enggal Kota Bandar Lampung. Tesis tidak diterbitkan. Lampung: Universitas Lampung.

Nurgiyantoro, Burhan. et al. (2012). Statistik Terapan (Untuk Penelitian Ilmu-ilmu Sosial). Yogyakarta: Gajah Mada University Press.

Nurgiyantoro, Burhan. et al. (2015). Statistik Terapan (Untuk Penelitian Ilmu- ilmu Sosial). (Edisi Revisi). Yogyakarta: Gajah Mada University Press

Prasetyo, Reni. (2013). Pelayanan Publik di Kecamatan Margoyoso Kabupaten
Pati. Tesis tidak diterbitkan. Semarang: Universitas Negeri Semarang.

Pratama, Andianto Wahyu Eka. (2014). Pengaruh Kualitas Pelayanan terhadap Kepuasan Masyrakat. Tesis tidak diterbitkan. Surakarta: Universitas Muhammadiyah Surakarta.

Sugiyono. (2017). Metode Penelitian Kuantitatif, Kualitatif, dan $R \& D$. Bandung: Alfabeta, CV.

Taufiqurokhman \& Satispi, Evi. (2018). Teori Perkembangan Manajemen Pelayanan Publik. Tangerang Selatan: UMJ PRESS.

Ulumudin, Aceng. (2014). Pengaruh Kualitas Pelayanan Administrasi Kependudukkan Terhadap Kepuasan Masyarakat. Jurnal Pembangunan dan Kebijakan. 4 (1): 1-6.

Purwanto, Agus Erwan \& Sulistyastuti, D.R. (2017). Metode Penelitian Kuantitatif. (Untuk Administrasi Publik dan Masalah-masalah Sosial). (Edisi 2). Yogyakarta: Gava Media. 


\section{PROGRESS}

Jurnal Pendidikan, Akuntansi dan Keuangan

Universitas Banten Jaya
Vol 3 No. 1, Februari 2020

E-ISSN 2622-7037 |P-ISSN 2623-0763 